Abstracta Iranicacta Iranica

Revue bibliographique pour le domaine irano-aryen

Volume 32-33 | 2013

Comptes rendus des publications de 2009-2010

\title{
Michael Jursa. On aspects of Taxation in Achaemenid Babylonia: new evidence from Borsippa
}

\section{Astrid Nunn}

\section{(2) OpenEdition}

1 Journals

Édition électronique

URL : http://journals.openedition.org/abstractairanica/40341

DOI : 10.4000/abstractairanica.40341

ISSN : 1961-960X

\section{Éditeur :}

CNRS (UMR 7528 Mondes iraniens et indiens), Éditions de l'IFRI

\section{Édition imprimée}

Date de publication : 1 décembre 2013

ISSN : 0240-8910

\section{Référence électronique}

Astrid Nunn, «Michael Jursa. On aspects of Taxation in Achaemenid Babylonia: new evidence from Borsippa ", Abstracta Iranica [En ligne], Volume 32-33 | 2013, document 84, mis en ligne le 01 juillet 2016, consulté le 28 septembre 2020. URL : http://journals.openedition.org/abstractairanica/40341 ; DOI : https://doi.org/10.4000/abstractairanica.40341

Ce document a été généré automatiquement le 28 septembre 2020.

Tous droits réservés 


\title{
Michael Jursa. On aspects of Taxation in Achaemenid Babylonia: new evidence from Borsippa
}

\author{
Astrid Nunn
}

\section{RÉFÉRENCE}

Michael Jursa. « On aspects of Taxation in Achaemenid Babylonia: new evidence from Borsippa ", in : Pierre Briant, Michel Chauveau, éds., Organisation des pouvoirs et contacts culturels dans les pays de l'empire achéménide. Paris, De Boccard, 2009, p. 237-269. (Persika 14)

De nombreuses études existent déjà sur le début de l'époque achéménide à Babylone et l'on sait que Cyrus et Darius respectèrent les institutions existantes. Il n'empêche que certains changements vont graduellement avoir lieu. L'A. traite la taxation, moins étudiée que d'autres domaines. Dans ce cas, les sources consistent en 130 textes inédits qui proviennent des archives de familles de prêtres à Borsippa. L'A. étudie la hiérarchie des recouvreurs d'impôts (le gugallu en était le responsable), comment ces impôts étaient calculés, en quoi ils consistaient et quand ils étaient payés.

\section{AUTEURS}

\section{ASTRID NUNN}

Université de Munich 